\title{
Historical Research as an Answer to Critical Political Questions: The Example of the Menten Case
}

\author{
J. C. H. BLOM
}

\section{Introduction}

Politicians occasionally request that historians conduct investigations in order to solve problems which are essentially political in characterpolitical because among other things the credibility and reputation of past and present politicians, indeed the careers of these politicians and of other public figures, are at stake. In the Netherlands during the period from 1966 to 1980 , leading politicians made several such requests. Three times historical investigations were required into real or alleged wrongdoings during World War II, and, occasionally, into the postwar reaction to such wrongdoings. (It was this postwar reaction that led to the challenging research task to be discussed here.) Each time, the political boat was severely rocked, and great pressure was brought to bear upon the cabinet to order an investigation. Because the government of the day had a direct stake in the findings, it was imperative that the investigation be conducted not by civil servants, but by independent researchers or a research committee specially set up for this purpose.

I will focus here on the research demands placed upon the shoulders of scholars engaged in "applied" or "public" history. As an example I will provide an account of the investigation of the so-called "Menten case," which I undertook with some colleagues. (I might add that the

This article is based on a lecture given at the Rotterdam conference on teaching and research in applied history, September 16-17, 1982. The author expresses his gratitude to Ilja Scholten for help with the translation of this lecture. 
case has already become nearly forgotten history, perhaps as a result of the success - from a historiographer's point of view - of our research.)'

\section{The Menten Affair, 1976-1981}

The political upheaval and public outcry which surrounded the Menten case in the summer of 1976 had a rather inconspicuous beginning. On May 22nd the largest-selling Dutch newspaper De Telegraaf published a full-page article about the then seventy-six-year-old Pieter Nicolaas Menten and his art collection, part of which was to be sold at a public auction because he was "cramped for space." The rather obvious purpose of the article was to draw attention to the auction, thereby raising the bidding prices. By coincidence, however, this article provided leads for journalist Hans Knoop, who at the time was working for the then struggling weekly magazine Accent, which has since folded. ${ }^{2}$ Knoop was investigating Menten at the suggestion of his Israeli colleague Chaviv Kanäan, who was convinced that Menten was a war criminal but who had been unable in the late forties and early fifties to persuade the Dutch Department of Justice to take action. Kanäan, in turn, had been tipped off by Henriëtte Boas, a Dutch correspondent. Very soon Knoop was able to supply ample evidence which, though incomplete, was nevertheless very incriminating for Menten. Knoop's articles and his direct involvement with a broadcasting organization, which pro-

1. Unless mentioned otherwise, all information in this article is to be found in the final report about the Menten case: J. C. H. Blom. A. C. I Hart, I. Schöfler met medewerking van (with the cooperation of) J. M. de Maar-Willink, De affaire-Menten 19451976 (Den Haag, 1979). For information on comparable investigations see the following. Concerning riots in Amsterdam in 1966: Eerste interim-rapport ian de commissie van onderaek Amsterdam (Den Haag. 1967) Tueede interim-rapport ian de commissie ian onderzoek Amsterdam (Den Ilata, 1967) and Slotrapport can de commissie van onderzoek Amsterdam (Den Haag, 1967). Concerning alleged violent excesses or even war crimes in Indonesia during the decolonization period (1945-1950): Nota betreffende het archievenonderzock natr gegevens omtrent excessen in Indonesië begaan door Vederlandse militairen in de periode 1945-1950 (Den Haag, 1969); J. A. A. van Doorn en W. J. Hendrix, Ontsporing ian geveld. Oeer het Vederlands/Indisch/Indonesisch conflict (Rotterdam, 1970). For an affair concerning F. Weinreb: D. Giltay Veth en A. J. van der Leeuw, Rapport door het Rijksinstitumt coor Oorlogsdocmmentatie uitgebracht aan de minister van justitie inzake de acticiteiten can des F. Weinreb gedurende de jaren 19401945, in het licht van nadere gegeeens bezien (Den Haag, 1976) and I. Schöller, "Weinreb, een affaire van lange duwr" in Tijdschrift voor Geschiedenis 95, no. 2(1982), 196224. Concerning the Lockheed affair and the role of Prince Bernhard: Rapport van de Commissie can Drie. Onderzoek natr de juistheid van verklaringen over betaling door een Amerikanse cliegtuigfabriek (Den Haag, 1976). Concerning the conduct of a leading Nember of Parliament. W. Aantjes, during the Second World War: Rapport can de Commissie can Drie in de zaak Aantjes (Den Haag, 1979) and Rapporl can de kamercommissie van onderzoek nat kennis omtrent gedragingen van m. W. Aantjes tijdens de Tweede Wereldoorlog (Den Hatag, 1979).

2. Knoop published the story of his activities on the Menten case early in 1977: 11. Knoop, De zaak-Menten (Amsterdam, 1977). One year later an English version was published: H. Knoop, The Menten-affair (New York: Macmillan, 1979). 
duced television programs about this case, drew national attention. Perhaps in poor taste, the scandal nevertheless appealed very much to the public imagination. Menten himself, in fact, welcomed the publicity and attempted to apply it to his advantage. He flatly rejected all accusations and argued that, as long ago as 1950, his case had been investigated and that he had been cleared of all charges. He frequently referred to public officials from those days by name. Most prominent of these was the former Speaker of the House, Dr. L. J. Kortenhorst. This Catholic politician had at the time been Menten's lawyer and had supposedly demonstrated his innocence of the charges.

In the public debate at least two distinct matters were confused. First, was Menten indeed a war criminal, and if so, how serious were the crimes which he committed? Was he actually a mass-murderer or an accessory to such acts? If so, should he still be prosecuted? Secondly, did Menten avoid prosecution or at least conviction after the war by bribing the judicial and political officials or by blackmailing them? If any of these charges were indeed true, wasn't it time that the facts about them were finally made public?

At first the Ministry of Justice opposed taking action. They considered the issue overblown-merely a passing public mood. They also wondered how strong the prosecutor's case would be, whether there would be sufficient reliable witnesses, and whether the case had not already been dealt with at an earlier date and then dismissed. The press displayed little sympathy for such arguments. To them this hesitation appeared in fact as heel-dragging. It seemed as if the Minister of Justice, A. A. M. Van Agt, preferred to turn a blind eye on the whole matter. After all, he had been in political hot water before when handling affairs involving war criminals. At that time he had wanted to pardon three Germun war criminals still in prison-the so-called "Three of Breda." Aiter many very emotional protests on the part of war vicrims, however, Van Agt withdrew his proposal. Now once again he appeared to be over-lenient and insensitive to the feelings of those who had suffered at the hands of the Nazis. Moreover, he was suspected of conspiring to protect those who twenty-five to thirty years earlier had been members of his own political party from possible revelations about corruption or political wrongdoings. Best known perhaps is the case of Dr. Kortenhorst, who has been accused of having used the influence of his position as speaker of the house on behalf of Menten in return for the (at that time) staggering sum of HH. 200,000 - in other words, to have received bribes.

The Ministry soon changed its attitude about prosecuting Menten, due not to the influence of the press or Parliament, but to the strength of the evidence. The Ministry made a preliminary legal investigation in July 1976. It would take too long to discuss in detail the course of these legal proceedings. Suffice it to say that it was very complicated, offering 
great excitement for the public, with many court sessions resulting in various differing verdicts. Not until 1981, after a long juridical struggle, was an irreversible verdict reached whereby Menten was declared guilty of war crimes in Poland. He was sentenced to ten years imprisonment and fined one hundred thousand guilders.

At first Minister of Justice Van Agt remained opposed to a special inquiry about the possibility that Menten had obtained protection during the immediate postwar years. However, extensive material relevant to the case emerged from the postwar years 1945 to 1955. In those early years Menten's name had repeatedly cropped up in the press and in official inquiries. One could even say that at that time there were several Menten cases. In addition, Menten exacerbated the embarrassment of the Department of Justice, and especially Minister Van Agt, by making a successful escape from the country, an escape cut short only by journalist Hans Knoop, who doggedly tracked him down. Suspicion of Menten, and also of Van Agt, increased steadily. Finally it became clear that the minister was no longer able to stave off public and parliamentary pressure. A number of fierce debates in Parliament followed. These forced the hand of Van Agt to initiate an official investigation into the proceedings surrounding the prosecution of Menten from the period immediately after the war until the summer of 1976, and into the role and effect of possible means of influence which affected the outcome of these prosecutions. This investigation was to be carried out by a specially appointed investigator or a group of investigators. ${ }^{3}$

For several reasons Van Agt was initially unable to find a qualified and prestigious investigator willing to take charge of such research. At last Dr. I. Schöffer, who holds the chair of Dutch history at Leyden University, said he was willing to form such an investigative committee, which he presented to the public at the beginning of 1977. Schöffer requested the cooperation of Dr. A. C. 't Hart, professor of criminal law at the Catholic University of Tilburg, and the author. Our official title was "The Committee of Investigation Concerning Menten." At the end of January we began our proceedings, with the initial expectation that it would not take very long to complete our work. Schöffer was thinking on the order of three months, but in fact this timetable was grossly overoptimistic. After having worked nearly full-time for 18 months, and then half-time for another year, we were able to present the final report, The Menten Case 1945-1976, in September 1979."

The so-called "Menten case" involved several extremely complicated

3. See the Parliamentary Papers: Handelingen Tweede Kamer der Staten-Generaal. Zitting 1976-1977, November 18, 1976, 1356-1403.

4. For the original Dutch title see footnote 1. J. M. de Maar-Willink is the clerk who assisted the committee. Her assistance was of such value that the committee decided that her name should be mentioned on the title page of the final report. 
affairs which could perhaps be examined as a set of separate cases, but which in fact are very much interconnected. Menten himself was not even directly involved in a number of these, including several court cases dealing with wartime behavior, crimes committed after the war, business transactions, claims for payment of compensation, perjury, and slander. The committee also had to investigate press manipulations and political manipulations, or at least attempts toward the latter. In our report we examined each of these cases separately in as detailed a manner as possible, and we tried to describe the various interlinkages.

We paid explicit attention to all suspicions and accusations related to these cases which had been raised up to 1976 and thereafter, even if there were no reasonable grounds to substantiate them. In addition we demonstrated that a convincing explanatory interpretation required careful examination of three main aspects. First, the exact chronological sequence of the events. Second, the fluctuations in the political moods which took place after the war in the Netherlands, especially with respect to the desirable treatment of political delinquents. (Later on the Cold War influenced the concept of what constituted desirable treatment.) Third, the very aggressive manner in which Menten, his lawyers, and other advisers defended his interests.

Following this approach we attempted to do more than merely research the scandals in which Dutch judicial and political officials had allegedly been involved. These officials certainly made mistakes. Often they had been slow in acting, and they handled a number of matters very clumsily. Moreover a number of their activities were questionable and deserving of condemnation. But on the whole no evidence turned up which demonstrated that the more serious and scandalous allegations were justified. In this respect the report was anticlimactic. Much more importantly, however, the report lived up to its main requirement-the reconstruction of the facts - and this reconstruction has not been challenged. The committee's interpretations elicited only a few negative comments. The reactions in the public media and professional circles were very complimentary to the activities of the committee. ${ }^{5}$ The publication of the report brought to an end this aspect of the Menten case which was formally wrapped up with a short parliamentary debate in February 1980. ${ }^{6}$

5. For reactions see the many publications in the press in September 1979, directly after the report had been published. The negative reactions came mostly from the judicial world, especially in relation to the court case that was still going on. For instance: N. E. Algra, Enkele juridische aspecten van de zaak-Menten (Groningen, 1978) and some articles in judicial periodicals.

6. See the Parliamentary Papers: Handelingen Tweede Kamer der Staten-Generaal. Zitting 1979-1980, February 6, 1980, 2796-2806. 


\section{Terms and Conditions of the Research}

When Professor Schöffer accepted his task on the last day of 1976 he stipulated in public a set of conditions. The most important of these were:

1) A promise of "support and finance" for the research, which meant that all requests for material support and human resources should be honored (such as, for example, clerical assistance, an accountant, a criminal investigator, secretarial assistance, travel allowances, physical accommodation, and the support of the judicial laboratory).

2) Full and complete freedom of scholarly research and reporting. This implied that neither the government nor the Ministry of Justice should hamper or attempt to influence the research and that, moreover, the report should be presented to Parliament in its complete form and also subsequently published in full.

3) That all documents which were in the governmental archives, and which according to the committee were relevant for the research, should be available. This condition was met in full although in two cases other ministries made objections. In one case the committee desired to consult documents which were in the archives of the "Internal Security Office" and in the second case it needed access to records of the internal revenue services. After consultation with the ministers heading these departments, we received permission after all.

4) All present and former civil servants were to be relieved of their obligation to withhold information on grounds of confidentiality and to be permitted to provide all information requested of them.

These conditions guaranteed both the independent status of the committee and completely free access to all relevant information, which was of crucial importance for the success of the investigation. The situation at the end of 1976, and indeed for a considerable time thereafter, was characterized by the existence of a substantial lack of trust in the integrity of the government. Any suggestion that the committee lacked independence or had less than full access to information immediately would have reduced the credibility of our findings. Moreover, this would also have circumvented the main objective of the research, which was to produce an account of the facts which was broadly accepted and which would as a result provide peace of mind for the politicians and the public.

\section{Research Problems}

Although the committee's research did not essentially deviate from the approach of other historical research, we encountered some prob- 
lems and circumstances characteristic of this type of research. First of all there is the matter of tracing documents. A government's promise to cooperate is not in itself sufficient, since the documents that one would like to examine need to be located. This turned out not always to be possible. In some cases the archives had been destroyed in line with official guidelines, while other archives had been lost for other reasons (especially in the chaos of the first months following the Second World War). Fortunately it was sometimes possible to locate particular materials, either the original documents or copies of them, by calling in the assistance of specialized archivists. Nevertheless, in the end there remained a list of documents which could neither be located nor accounted for. This provided fuel for rumors that evidence which incriminated either Menten or certain public officials had been destroyed deliberately, and in fact such suspicions were voiced in the public media. This deliberate destruction of evidence had allegedly taken place between 1945 and 195.5, although later dates were suggested, such as summer and autumn 1976, when the Menten case had received renewed attention but the investigation had not yet started. For our purposes, the alleged destruction of documents did not matter very much, since the missing documents were not needed to complete the overall picture. Moreover, nothing suggested any deliberate destruction or removal of evidence. Nevertheless, the absence of these documents might have reduced the credibility of the final report. Fortunately, we found some very important dossiers, purely by coincidence.

These dossiers, which incidentally also proved to be very important later on in the court case against Menten, contained the files of the most important lawsuits against Menten during the period 1945-1955. According to the public media, these files had been lost deliberately. They were found together with several other documents hidden behind a file case in the attic of the Palace of Justice in Amsterdam. In 1955 the attorney general in Amsterdam (in the Netherlands a high-ranking public prosecutor) had kept these and other documents separate from the regular archives because of their delicate nature. Since then they were moved a few times and in 1976 and 1977 only one person remained who knew of the documents which were hidden among various kinds of rubbish. He had not made the connection with the Menten case, but when some other names were mentioned he remembered the existence of these documents. So the Menten files eventually re-emerged, discrediting those who argued that the documents had been stolen.

Our research was hampered, however, in other ways. Only a few private archives provided us with additional information. And most lawyers maintained that, regardless of the age of the files in question, examination of them would constitute a threat to the confidential character of their relation with their clients. They therefore refused to have them examined-in our opinion quite rightly so. 
Altogether different was the issue with respect to the files held in the family archives of Menten's former lawyer, the aforementioned Dr. Kortenhorst. There were at least several reasons why in this case "confidentiality" could not be invoked as a persuasive excuse to refuse access to them, and initially the family did not use this argument. The fact was that they considered the committee to be their acknowledged enemy. Their lack of cooperation did not hamper our research to a large extent, but the fact remains that others, notably the lawyer representing Menten in a fresh war criminal case, were permitted to examine these files. Significantly, they revealed nothing new or startling. In fact, they even failed to produce those documents which existed according to Menten and which were supposedly very favorable to his defense, though incriminating to several politicians who had served as ministers of justice during the early 1950s. The committee doubts that these documents ever existed at all. Nevertheless, when the committee had completed its research and presented it publicly, we were challenged and were forced to concede that we had not been allowed to examine the Kortenhorst archives. Such files would normally have constituted an important component of the kind of research conducted by the committee. This (imposed) omission, therefore, was very unfortunate indeed. In the evaluations of the report this omission has been mentioned frequently.

Another problem concerns contact with "witnesses" and their testimonials. The committee wanted to talk to as many of those people who had been involved with the Menten case(s) as possible. We contacted about 150 people, on the whole with very disappointing results. The explanation for this is rather simple: most of these people were civil servants who had been involved in some capacity with one of the many cases which the committee was researching. Most of the information we wanted concerned the details of cases which had taken place twenty-five years ago. Understandably, memories from so long ago were dim, and on balance, the information obtained from the files proved considerably more reliable. Moreover, several people who were at the time closely associated with Menten refused to cooperate. Menten himself broke off all contacts with the committee after a few interviews. During these conversations he made some rather obvious attempts to get the committee entangled in the current court case against him. It is a pity that we had so little cooperation from these circles, because otherwise we could have explained some aspects of the behavior of Menten and his consorts more satisfactorily. During the period from 1945 to 1955 , however, Menten and his "party" had produced such an abundance of material that information highlighting their point of view was readily available.

The conclusion must be that the oral history method is not particularly suitable for this type of research. Only in a few cases was useful information obtained as a result of the personal contact with the people 
involved in these cases. I hasten to add that this observation is not intended as a general evaluation of the methodology of oral history per se. This method can be applied very successfully, but to research of a different nature. In retrospect it was perhaps predictable that this method yielded limited results. Details were of prime importance for our research, and several of the people interviewed still had direct interests at stake. However, the credibility of our research would have suffered if we had omitted such interviews.

Another complication was brought about by the fact that the court case pertaining to Menten's behavior during the war took place at the same time as our research. Thus there was the constant danger that the committee would become entangled in the court case. (Menten, in fact, wanted this to happen.) Despite the careful defining of the issues and the separation of cases concerning Menten's behavior during the war from cases dealing with postwar developments, it proved to be impossible to separate clearly the respective investigations. In the court case the judicial developments after the war were relevant in connection with the judicial procedure of ne bis in idem, which states that a person cannot be brought to trial twice for the same offense. As a consequence, the committee and the judges not only had to study the same documents, but they also had to come up with an interpretation of the same problems.

Several problems arose due to this entanglement of investigations. At the start of its research the committee made an unfortunate and rather naive mistake when it let the examining magistrate look at a very provisional draft of a list of dates, which ended up in the actual dossiers of the court case. Later on it became clear that this list contained several errors. Menten's lawyer used one of these errors as part of his defense case, and naturally this aroused undesirable publicity for the committee.

The committee faced another thorny problem when in the court proceedings a particular issue became very important. Once the committee had completed its "reconstruction" of this issue it decided that, given the developments in court, it should not withhold the results of its research. So the committee published an "interim report," thereby risking the possibility of standing accused of interference in the proceedings of a criminal investigation. The court's reconstruction differed, unfortunately, from the one by the committee. Although the verdict was annulled in appeal, the committee felt obliged to discuss this question in the final report, because it considered the court's reconstruction to be based on false grounds. This course of events attracted a lot of unfavorable public attention. Although inevitable, proceedings of this nature can hardly be considered a showcase of judicial elegance. Fortunately, these developments did not tarnish all of the committee's work, especially since its interpretation was not convincingly challenged. 
The eager interest of the press also presented some problems. To some extent the very existence of the committee was brought about by the activities of the press. After all, newspaper publications provided the momentum which built up sufficient parliamentary pressure upon the cabinet to set up an inquiry. Moreover, the discoveries of several journalists had provided a basis from which the research could proceed. So there was in fact every reason to have a positive attitude toward the press. However, this very same eagerness of the press was potentially disturbing to our research activities. Shortly after beginning its research the committee attempted to court the press by inviting all those journalists who had produced valuable publications about the Menten case to discuss their work. The committee inquired extensively in to the journalists' sources and interpretations. Because the committee had just begun its research, it was unable to provide anything in exchange at that time. We explained to the journalists that we were going to make a careful and original inquiry into these cases, strongly resisting any outside influence. Only after completion of our task would we publish a final report, and no interim information would be provided to the press. The committee pleaded for understanding regarding this position and on the whole, our request was honored. With few exceptions, such as the one mentioned above, ${ }^{7}$ relatively little publicity about our research appeared at that time. The fact that the journalists themselves did not come up with anything of real significance after the committee was established was helpful, because it meant that the journalists did not have any incentive for further publications besides reporting on the developments in court. After the committee had completed its research and published the final report we stated our willingness to respond to any questions which the press wished to direct to us, though in fact all relevant information could be found in this final report.

\section{Final Report}

Several important decisions preceded the determination of what should be included in the committee's final report. Foremost was the question of how detailed the report should be. On the one hand it was desirable to be brief and to prevent wasting energy on relatively unimportant aspects, while on the other hand so much excitement had been aroused that a detailed account seemed desirable. After careful consideration the committee decided on a detailed report. Since the research had been intended to calm the waters by providing reliable information, it was imperative that no questions be left hanging in the air.

7. Another exception was the journalist N. Polak, who published about the Menten case in Het Vrije Volk in De Haagsche Post. For his views and the comments of the committee on them see the report of the committee. 
Each and every open question and every fact which third parties (such as the press) might legitimately argue had been omitted by the committee would provide a basis for undermining the conclusions of the research. This is the main reason for the length of the report (922 pages). (In relation to Dutch history as a whole, this case was much less important than the size of the report would suggest.) The committee presented the report in a format which made the central issues stand out, while the more peripheral ones were presented either in footnotes or printed in small lettering, enabling the reader to skip those parts without losing the thread of the argument.

The committee also had to decide whether to publish the most important documents and accompany them with a limited amount of commentary, ${ }^{s}$ or whether to write an extensive report providing references to the original documents in footnotes. For two primary reasons, the committee decided to follow the latter course. First, the number of documents which would have to be published to enable the reader to reconstruct the case would be so large that the resulting publication would have been much more voluminous than the existing (already very sizeable) report. (In fact, readers would not have been able to find their way through such a maze without spending several months.) This consideration would have sufficed in itself. Moreover, while it may seem that the publication of the actual documents is more objective than a story produced by historians, this is not really so. After all, the very selection of the documents would have reflected the subjective interpretation of the historians. As a matter of principle, therefore, it is more legitimate for investigators to present their findings in a narrative fashion. The committee's publication contained, first of all, a chronological and thematic history followed by a number of concluding remarks which link up the main interpretative elements; secondly, an account of the sources used; and finally, an illustrative sample of the most important documents.

Closely related is one last issue-value judgments on the part of historians. On the whole I feel it is preferable for historians to restrain themselves, expressing as few moral and political judgments about the people whose actions they describe as possible. The objective of historical research is the reconstruction of events and the accompanying analytical explanatory evaluations (the interpretation). The latter have to be clearly and explicitly stated. In this case, however, issues of a political and moral character brought about the research in the first place. Consequently, their omission would have seemed contrived. This is why, in addition to the analytic explanatory judgments, the committee at times expresses approval or disapproval of the behavior of various parties. The committee did attempt to restrain its tone and to display an

8. The committee in the Aantjes affair and the committee in the Amsterdam riots problem (see footnote 1), both under the leadership of Professor Ch. J. Enschedé, took this line. 
understanding of the situation at the time that these acts took place. After all, it was not the committee's task to serve as hangman, and the committee had the benefit of hindsight and the necessary time to weigh the arguments after examining the case from all angles. The public officials who dealt with such cases at the time were handling many cases simultaneously and their time was quite limited. The committee took these considerations into account when formulating its concluding opinions. Readers of the report must decide whether the committee was fair. However, we maintain that on the whole we succeeded in reaching our main objective, which was to clear up all questions concerning the Menten case(s).

In closing, I would like to point to a side effect of research like ours. Although our project originated from the desire to contribute to the solving of an immediate political problem, it turned out to have wider significance. As some professional historians reacting to our work have claimed, ${ }^{9}$ our report also makes a useful contribution to the scholarly historiography of the postwar period.

9. Up to now there has been only one scholarly historical review in Tijdschrift voor Geschiedenis 93, no. 4 (1980), 681-83. In addition to this the chairman of the Dutch Historical Association, Professor E. H. Kossmann may be quoted. In his introduction to an unpublished lecture by Schöffer he said that the report is "much more than a report, it is rather an independent, excellently constructed, and extremely readable historiography" (Bijdragen en Mededelingen betreffende de Geschiedenis der Nederlanden 95, no. 1 [1980], 247). 


\section{Forward with History: Studying the Past for Careers in the Future}

Peter J. BECK

IN 1980 MY DISCussion of the role of history in higher education in Britain was accompanied by an illustration showing the subject-symbolized as an "ivory tower" and with such key historical figures as Napoleon and Hitler peeping somewhat nervously from the battlements at the mob below-under pressure, if not serious threat, from the outside world. ${ }^{1}$ During the same year, Joan Hoff Wilson, then of Arizona State University, was reminding readers of The Public Historian of the job market crisis and of the possibility that the historical profession was "an endangered species." As these examples indicate, historians on both sides of the Atlantic, having retired to "the academic closet" and kept their distance from society, have been forced to re-appraise their position, and especially to consider stepping out into the marketplace. Hence the development of the public history movement in the United States. ${ }^{3}$ For most British historians, however, and one suspects this is true also for the United States in spite of public history, the ivory tower is still the reassuring reality, even if it is becoming more difficult to ignore the "mob below"-the escalating series of pressures from the world outside of academia.

The historical profession in both Britain and the United States has been and is still subjected to similar pressures. In the light of this

The author wishes to thank the American Embassy in London for fiscal support of his research visit to the United States during which he attended the 1982 Public History Conference.

1. Peter Beck, "Knowledge of the Past that Helps to Shape the Future," The Times Higher Education Supplement, July 4, 1980, 10-11.

2. Joan Hoff Wilson, "Is the Historical Profession an "Endangered Species"?" The Public Historian 2, no. 2(Winter 1980), 4.

3. Terence O'Donnell, "Pitfalls Along the Path of Public History," The Public Historian 4, no. 1 (Winter 1982), 65-66. 